\title{
Perlindungan Hukum Terhadap Anak Sebagai Korban Tindak Pidana Penganiayaan Ditinjau Dari Undang-Undang Perlindungan Anak
}

\author{
Nova Ardianti Suryani* \\ ${ }^{1,2}$ Program Studi Hukum, Fakultas Hukum, Universitas Muhammadiyah Yogyakarta, Indonesia \\ *Korespondensi: novasuryani27@gmail.com
}

\section{Artikel Info}

Submitted: 20-03-2020

Reviewed: 26-03-2020

Revised: 30-03-2020

Accepted: 31-03-2020

DOI:10.18196/mls.v2i2.11493

\begin{abstract}
Abstrak
Perlindungan anak merupakan bagian dari implementasi dari nilai-nilai hak asasi manusia. Hal ini memiliki tujuan untuk melindungi hak-hak anak untuk hidup, tumbuh, berkembang dan berpartisipasi secara maksimal dalam masyarakat. Adanya hak-hak anak sebagai korban tindak pidana penganiayaan belum sepenuhnya terpenuhi, seperti rehabilitasi psikis dan ganti rugi terhadap korban. Penelitian ini bertujuan untuk mengetahui tentang pengaturan hak-hak anak sebagai
\end{abstract} korban tindak pidana penganiayaan dan untuk mengetahui tentang ketentuan hukum yang mengatur perlindungan hukum terhadap anak. Metode penelitian skripsi ini menggunakan pendekatan normatif yaitu menganalisis data sekunder yang merupakan data yang diperoleh dengan cara penelitian kepustakaan, yang berupa bahan hukum primer yaitu peraturan perundang-undangan, bahan hukum sekunder yaitu buku-buku, jurnal, atau media online dan bahan hukum tersier yaitu kamus hukum dan kamus Bahasa Indonesia. Kesimpulan penelitian skripsi ini menunjukkan hasil dari pengaturan hak anak sebagai korban tindak pidana penganiayaan yaitu dengan melihat hak-hak korban yang terdapat dalam peraturan perundang-undangan dan hak-hak yang didapat oleh korban tindak pidana. Sedangkan ketentuan hukum mengatur perlindungan hukum terhadap anak yaitu dengan menentukan peraturan yang dilanggar dari tindak pidana tersebut dengan mempertimbangkan berat dan ringannya pidana yang dijatuhkan. Peraturan yang digunakan sebagai acuan dalam penelitian ini adalah Pasal 80 Ayat (1) Undang-undang No. 35 tahun 2014 tentang Perubahan atas Undang-undang No. 23 tahun 2002 tentang Perlindungan Anak.

Kata Kunci: hak anak, perlindungan anak, tindak pidana penganiayaan.

\section{Pendahuluan}

Negara Indonesia adalah negara hukum (rechtstaat) dimana hukum pada dasarnya bertujuan untuk mencapai kedamaian hidup bersama, yang merupakan keserasian antara ketertiban dan ketentraman. Hal ini tersirat dalam pembukaan Undang-Undang Dasar 1945 alinea IV dimana disebutkan bahwa tujuan negara Indonesia yang melindungi segenap bangsa Indonesia dan seluruh tumpah darah Indonesia, memajukan kesejahteraan umum, mencerdaskan kehidupan bangsa, dan ikut melaksanakan ketertiban dunia. Dalam hal Indonesia sebagai negara hukum tercermin dalam Pasal 1 ayat 3 Undang-Undang Dasar Republik Indonesia tahun 1945 menegaskan bahwa "Negara Indonesia adalah negara hukum" serta dalam Pasal 28 G Undang-Undang Dasar 1945 menegaskan mengenai perlindungan hak asasi manusia.

Sebagai negara hukum, Indonesia memberikan perlindungan bagi setiap warga negaranya dengan cara menyediakan lembaga yang mampu memberikan keadilan dalam 
bentuk peradilan yang bebas dan netral. Hal ini didasari setiap manusia sejak kelahirannya mempunyai hak-hak dan kewajiban yang bersifat bebas dan asasi, negara beserta penyelenggaraan kekuasaan di suatu negara tidak diperbolehkan mengurangi makna kebebasan dan hak-hak asasi kemanusiaan tersebut.

Bentuk perlindungan terhadap masyarakat yang dilakukan oleh negara salah satunya ialah memberikan perlindungan hukum melalui proses peradilan apabila terjadi tindak pidana. Salah satu pihak yang sangat membutuhkan perlindungan dalam suatu tindak pidana adalah korban tindak pidana. Pentingnya korban untuk diberikan perhatian dan perlindungan bermula dari pemikiran bahwa korban merupakan pihak yang dirugikan dalam terjadinya suatu tindak pidana, sehingga harus mendapatkan perhatian dan pelayanan dalam memberikan perlindungan terhadap kepentingannya.

Korban tindak pidana lemah dalam perlindungan hukum, sejak korban melaporkan terjadi tindak pidana dan menunjukkan siapa pelaku tindak pidana dan atau dengan menyerahkan barang bukti dan ditemukan ditempat kejadian Putusan termasuk penderitaan baik fisik maupun non fisik serta kerugian materiil dan kerugian non materiil kepada aparat penegak hukum. Dengan korban telah melaporkan hal tersebut, maka korban tidak memiliki akses untuk mendapat foto copy arsip laporan polisi. Berita acara pemeriksaan korban/pelapor dan saksi, surat perintah penyidikan, surat perintah penuntutan, berkas Putusan yang diserahkan kepada jaksa penuntut umum, pelimpahan tersangka dan barang bukti kepada jaksa penuntut umum, pelimpahan surat dakwaan kepada pengadilan negeri, dakwaan dan tuntutan pidana serta putusan pengadilan negeri apalagi untuk mendapatkan kompensasi atas penderitaan dan kerugian yang diderita oleh pihak korban sampai mempunyai kekuatan hukum tetap. ${ }^{1}$

Maraknya kasus kekerasan pada anak sejak beberapa tahun ini seolah membalikkan pendapat bahwa anak perlu dilindungi. Dewasa ini begitu banyak anak yang menjadi korban kekerasan keluarga, lingkungan maupun masyarakat. Pasal 28b ayat (2) Undang-undang Dasar Republik Indonesia tahun 1945 menyatakan bahwa ;

"Setiap anak berhak atas kelangsungan hidup, tumbuh, dan berkembang serta berhak atas perlindungan dari kekerasan dan diskriminasi”.

Kekerasan sering dilakukan bersamaan dengan salah satu bentuk tindak pidana, tindak kekerasan dapat dilakukan dengan kekerasan atau ancaman kekerasan dilakukan atau alat apa yang dipakai, masing-masing tergantung pada kasus yang timbul. Perbuatan tersebut dapat menimpa siapa saja, baik laki-laki maupun perempuan, dari anak-anak sampai dewasa, apalagi kalau kekerasan terjadi dalam ruang lingkup rumah tangga, seringkali tindak kekerasan ini disebut hidden crime (kejahatan yang tersembunyi) disebut demikian, karena baik pelaku maupun korban berusaha untuk

\footnotetext{
${ }^{1}$ Abdussalam, 2010, Victimology, Jakarta: PTIK Press, hlm. 36
} 
merahasiakan perbuatan tersebut dari pandangan publik, kadang juga disebut domestic violence (kekerasan domestik). ${ }^{2}$

Banyak kekerasan yang dialami oleh anak-anak, khususnya yang berusia di bawah 18 tahun pada saat ini. Kebanyakan dari kasus-kasus tersebut adalah penganiayaan yang dilakukan secara bersama-sama atau berkelompok. Hal ini terjadi karena banyak anakanak yang memiliki kelompok bermain dengan beberapa temannya yang lama kelamaan kelompok tersebut menjadi sebuah geng. Dalam geng inilah sering terjadi perkelahian antar geng lain atau bahkan mereka tak segan untuk menganiaya seorang individu. Tentunya penganiayaan ini menimbulkan adanya korban. Banyak factor yang menjadi timbulnya sebuah tindak penganiayaan, misalnya dendam kelompok anak tersebut, dendam pribadi, masalah sepele, dan masih banyak lagi yang lainnya.

Banyak di antara para korban yang memilih jalur hukum untuk menyelesaikan permasalahan ini dengan harapan mendapatkan keadilan dan memberikan efek jera atau pelajaran bagi pelaku tindak penganiayaan. Tetapi tidak sedikit pula yang memilih diam dan bungkam karena alasan tidak ingin memperpanjang masalah. Padahal sudah ada Undang-undang Perlindungan Anak yang mengatur setiap tindak pidana yang dilakukan oleh dan/atau terhadap anak. Di dalamnya pun sudah diatur tentang perlindungan hukum bagi korban kekerasan.

Setiap orang yang melakukan pemeliharaan anak harus memperhatikan dan melaksanakan kewajibannya, yang merupakan hak-hak anak peliharaannya. Pasal 2 Undang-undang No. 4 Tahun 1979 tentang Kesejahteraan Anak menentukan bahwa hak-hak anak berupa: kesejahteraan, perawatan, asuhan, bimbingan, pelayanan untuk mengembangkan kemampuan dan kehidupan sosialnya, pemeliharaan dan perlindungan dari lingkungan baik semasa dalam kandungan maupun sesudah dilahirkan, perlindungan dari lingkungan hidup yang dapat membahayakan pertumbuhan dan perkembangannya. $^{3}$

Pasal 15 Undang-Undang Nomor 35 tahun 2014 ditentukan bahwa setiap anak berhak untuk memperoleh perlindungan dari:
a. Penyalahgunaan dalam kegiatan politik
b. Pelibatan dalam sengketa bersenjata
c. Pelibatan dalam kerusuhan social
d. Pelibatan dalam peristiwa yang mengandung unsur kekerasan
e. Pelibatan dalam peperangan, dan
f. Kejahatan seksual

\footnotetext{
2 Moerti Hadiati Soeroso, 2010, Kekerasan Dalam Rumah Tangga Dalam Perspektif Yuridis Viktimologis, Jakarta: Sinar Grafika, hlm. 1

${ }^{3}$ Maidin Gultom, 2014, Perlindungan Hukum Terhadap Anak Dalam Sistem Peradilan Pidana Anak di Indonesia, Bandung: Refika Aditama, hlm. 2
} 
Dalam Pasal 2 Undang-undang No. 4 tahun 1979 tentang Kesejahteraan Anak, disebutkan bahwa:

1. Anak berhak atas kesejahteraan, perawatan, asuhan, dan bimbingan berdasarkan kasih saying, baik dalam keluarganya maupun dalam asuhan khusus untuk tumbuh dan berkembang dengan wajar.

2. Anak berhak atas pelayanan untuk mengembangkan kemampuan dan kehidupan sosialnya, sesuai dengan kebudayaan dan kepribadian bangsa, untuk menjadi warga Negara yang baik dan berguna.

3. Anak berhak atas pemeliharaan dan perlindungan, baik semasa kandungan maupun sesudah dilahirkan.

4. Anak berhak atas perlindungan terhadap lingkungan hidup yang dapat membahayakan atau menghambat pertumbuhan dan perkembangan dengan wajar.

Undang-undang Perlindungan Anak telah menyebutkan perlindungan terhadap anak, namun pada penerapannya terdapat perbedaan dalam perlindungan terhadap anak yang menjadi korban tindak pidana dalam kasus penganiayaan. Sebagaimana terhadap putusan Nomor 4/Pid.Sus.Anak/2018/PN Smn dan putusan Nomor 14/Pid.Sus.Anak/2019/PN Smn yang memutus perkara tindak pidana penganiayaan yang korbannya adalah anak.

Hal penting yang perlu diperhatikan dalam peraturan perundang-undangan yang berkaitan dengan anak adalah konsekuensi penerapannya dikaitkan dengan berbagai faktor seperti kondisi ekonomi, sosial politik dan budaya masyarakat. Pengaturan hak anak sebagai korban tindak pidana penganiayaan dan ketentuan hukum dalammengatur perlindungan hukum terhadapap anak merupakan permasalahan yang ingin di kaji pada tulisan ini. Dalam berbagai peraturan perundang-undangan terdapat perbedaan ketentuan yang mengatur tentang anak, hal yang dilatarbelakangi berbagai faktor yang merupakan prinsip dasar yang terkandung dalam dasar pertimbangan dikeluarkannya peraturan perundang-undangan yang bersangkutan yang berkaitan dengan kondisi dan perlindungan anak.

\section{Metode Penelitian}

Jenis penelitian yang dilakukan oleh peneliti ini termasuk dalam penelitian normatif yang menganalisis permasalahan yang dilakukan dengan cara studi pustaka terhadap bahan-bahan hukum yang merupakan data sekunder yang diperoleh dan terkait dengan perlindungan hukum terhadap anak yang menjadi korban penganiayaan. Dalam menganalisis bahan hukum yang diperoleh dari hasil penelitian, peneliti menggunakan metode analisis deskriptif kualitatif, yaitu menyusun, mengolah dan membahas hasil data kualitatif yang diperoleh dari hasil studi kepustakaan dalam penelitian ini. Dari 
hasil analisis bahan hukum yang diperoleh, selanjutnya akan ditarik kesimpulan pada tahap akhir.

\section{Hasil dan Pembahasan}

\subsection{Pengaturan Hak Anak Sebagai Korban Tindak Pidana Penganiayaan}

Tindak pidana penganiayaan adalah suatu perbuatan yang dilakukan secara sewenang-wenang menyebabkan rasa sakit dan luka pada tubuh orang lain. Dengan kata lain untuk menyebut seseorang telah melakukan penganiayaan, maka orang tersebut harus memiliki kesengajaan dalam melakukan suatu perbuatan untuk membuat rasa sakit pada orang lain atau luka pada tubuh orang lain dalam perbuatannya sehingga merugikan kesehatan orang lain.

Dalam Kitab Undang-Undang Hukum Acara Pidana, diatur beberapa hak yang dapat digunakan oleh korban penganiayaan dalam suatu proses peradilan pidana, yakni sebagai berikut :

1. Hak untuk melakukan kontrol terhadap penyidik dan penuntut umum

2. Hak korban berkaitan dengan kedudukannya sebagai saksi.

3. Hak untuk menuntut ganti rugi akibat suatu tindak penganiayaan yang menimpa diri korban

4. Hak bagi keluarga untuk mengizinkan atau tidak mengizinkan polisi melakukan otopsi.

Berkaitan dengan hak korban untuk mengajukan tuntutan ganti rugi melalui cara penggabungan Putusan sebagaimana diatur dalam Pasal 98 sampai 101 KUHAP. Pihakpihak yang berkepentingan perlu memperhatikan beberapa hal, yaitu sebagai berikut :

1. Kerugian yang terjadi harus ditimbulkan oleh tindak pidana itu sendiri.

2. Kerugian yang ditimbulkan oleh tindak pidana atau orang lain yang menderita kerugian (korban) sebagai akibat langsung dari tindak pidana tersebut.

3. Gugatan ganti kerugian yang diakibatkan tindak pidana tadi ditujukan kepada sipelaku tindak pidana (terdakwa).

4. Dan, tuntutan ganti rugi yang diajukan kepada terdakwa tadi digabungkan atau diperiksa dan diputus sekaligus bersamaan pada pemeriksaan dan putusan Putusan pidana yang didakwakan kepada terdakwa dan dalam bentuk satu putusan.

Dalam Pasal 2 Undang-undang No. 4 tahun 1979 tentang Kesejahteraan Anak, disebutkan bahwa:

1. Anak berhak atas kesejahteraan, perawatan, asuhan, dan bimbingan berdasarkan kasih saying, baik dalam keluarganya maupun dalam asuhan khusus untuk tumbuh dan berkembang dengan wajar. 
2. Anak berhak atas pelayanan untuk mengembangkan kemampuan dan kehidupan sosialnya, sesuai dengan kebudayaan dan kepribadian bangsa, untuk menjadi warga Negara yang baik dan berguna.

3. Anak berhak atas pemeliharaan dan perlindungan, baik semasa kandungan maupun sesudah dilahirkan.

4. Anak berhak atas perlindungan terhadap lingkungan hidup yang dapat membahayakan atau menghambat pertumbuhan dan perkembangan dengan wajar.

Pasal 1 angka 3 Undang-Undang Republik Indonesia Nomor 31 Tahun 2014 Tentang Perubahan Atas Undang-Undang Nomor 13 Tahun 2006 tentang perlindungan Saksi dan Korban disebutkan bahwa korban adalah seseorang yang mengalami penderitaan fisik, mental, dan/atau kerugian ekonomi yang diakibatkan oleh suatu tindak pidana. Ketentuan Pasal 5 Undang-Undang ini menentukan adanya saksi dan korban mempunyai hak serupa :

a. Memperoleh perlindungan atas keamanan pribadi, Keluarga, dan harta bendanya, serta bebas dari Ancaman yang berkenaan dengan kesaksian yang akan, sedang, atau telah diberikannya;

b. Ikut serta dalam proses memilih dan menentukan bentuk perlindungan dan dukungan keamanan;

c. Memberikan keterangan tanpa tekanan;

d. Mendapat penerjemah;

e. Bebas dari pertanyaan yang menjerat;

f. Mendapat informasi mengenai perkembangan kasus;

g. Mendapat informasi mengenai putusan pengadilan;

h. Mendapat informasi dalam hal terpidana dibebaskan;

i. Dirahasiakan identitasnya;

j. Mendapat identitas baru;

k. Mendapat tempat kediaman sementara;

1. Mendapat tempat kediaman baru;

m. Memperoleh penggantian biaya transportasi sesuai dengan kebutuhan;

n. Mendapat nasihat hukum;

o. Memperoleh bantuan biaya hidup sementara sampai batas waktu perlindungan berakhir; dan/atau

p. Mendapat pendampingan. 
Pasal 90 ayat (1) Undang-Undang Nomor 11 tahun 2012 tentang Sistem Peradilan Pidana Anak menjelaskan bahwa Anak Korban dan Anak Saksi berhak atas upaya rehabilitasi medis dan rehabilitasi social, baik di dalam Lembaga maupun di luar Lembaga. Selain hak-hak tersebut, terdapat beberapa hak anak sebagai korban untuk mendapatkan bantuan media dan bantuan rehabiltasi psiko-sosial.

Pemenuhan hak-hak anak sebagai korban tindak pidana penganiyaan pada kedua Putusan tersebut di atas secara spesifik dapat dijabarkan sebagai berikut:

a. Hak untuk melakukan kontrol terhadap penyidik dan penuntut umum

Pada kasus nomor 4/Pid.Sus-Anak/2018/PN.Smn korban mendapatkan haknya dalam hal dapat melakukan pelaporan dan penuntutan dalam kapasitasnya sebagai pihak yang mengalami tindak pidana penganiayaan. Dalam proses pelaporan korban juga telah mendapatkan haknya untuk memperoleh tindakan visum sebagai alat bukti pelaporan. Korban melaporkan pada tanggal 27 Februari 2008 atas tindak penganiayaan yang dilakukan oleh Pelaku kepadanya. Pelaporan ini dilakukan oleh korban secara langsung.

Sedangkan pada Putusan Nomor 14/Pid.Sus.Anak/2019/PN Smn korban mendapatkan haknya dalam melakukan pelaporan atas apa yang menimpa korban kepada pihak berwajib. Kasus ini dapat berjalan karena korban menceritakan kejadian yang menimpanya kepada saksi. Kemudian korban melakukan Visum Et Repertum. Dengan adanya hal Visum dan kesaksian tersebut kemudian digunakan untuk membuat pelaporan.

b. Hak korban berkaitan dengan kedudukannya sebagai saksi dengan memberikan keterangan tanpa tekanan

Pada Putusan Nomor 4/Pid.Sus-Anak/2018/PN Smn korban telah mendapatkan hak-haknya yang berkaitan dengan kedudukannya sebagai saksi dalam pelaporan tindak pidana penganiayaan yang dilakukan oleh pelaku. Korban dapat dengan jelas menceritakan kronologi yang di alaminya berkaitan dengan tindak penganiayaan yang dilakukan oleh Pelaku. Korban mendapatkan penasihat hukum yang juga bertindak sebagai jaksa penuntut umum dalam persidangan yang di lakukan. Korban juga telah mendapatkan haknya sebagai saksi untuk memperoleh perlindungan atas keamanan pribadi, keluarga dan harta benda serta bebas dari ancaman yang berkenaan dengan kesaksian yang akan, sedang, atau yang telah diberikan, di tinjau dari keputusan yang diberikan atas penahanan pelaku

Hak korban pada Putusan Nomor 14/Pid.Sus.Anak/2019/PN Smn korban telah mendapatkan haknya dengan menjadi saksi dalam Putusan tersebut. Korban juga mendapatkan penasehat hukum yang bertindak sebagai penuntut umum dalam persidangan. Korban juga mendapatkan haknya dalam hal keamanan pribadi, keluarga dan harta benda serta bebas dari ancaman yang berkenaan dengan kesaksian yang akan, sedang, atau telah diberikan ditinjau dari hasil putusan yang diberikan kepada pelaku sebagai akibat dari perbuatannya. 
c. Hak untuk mendapatkan informasi mengenai putusan pengadilan.

Korban pada Putusan Nomor 4/Pid.Sus-Anak/2018/PN.Smn mendapatkan informasi mengenai putusan pengadilan untuk kasus tersebut, dengan dikeluarkannya hasil putusan pengadilan terhadap pelaku. Demikian pula dengan Putusan Nomor 14/Pid.Sus.Anak/2019/PN.Smn korban juga mendapatkan informasi mengenai putusan pengadilan dalam kasus yang dihadapi oleh korban.

d. Hak bagi keluarga untuk mengizinkan atau tidak mengizinkan polisi melakukan otopsi.

Pada Putusan Nomor 4/Pid.Sus-Anak/2018/PN.Smn keluarga korban tindak pidana penganiayaan tidak menggunakan haknya untuk menerima ataupun menolak proses otopsi dikarenakan proses penyelidikan tidak membutuhkan data pendukung yang hanya bisa diperoleh dari proses otopsi. Hal tersebut juga sama pada Putusan Nomor 14/Pid.Sus.Anak/2019/PN.Smn

Tabel 1. Perbandingan pengaturan Hak Anak sebagi Korban Tindak Pidana Penganiayaan yang terdapat dalam kasus

\begin{tabular}{|c|c|c|c|}
\hline No & $\begin{array}{l}\text { Hak Anak sebagai } \\
\text { Korban }\end{array}$ & $\begin{array}{l}\text { Putusan Nomor 4/Pid.Sus- } \\
\text { Anak/2018/PN.Smn }\end{array}$ & $\begin{array}{l}\text { Putusan } \\
\text { 14/Pid.Sus.Anak/2019/PN.S } \\
\mathrm{mn}\end{array}$ \\
\hline 1. & $\begin{array}{l}\text { Hak untuk melakukan } \\
\text { kontrol terhadap } \\
\text { penyidik dan penuntut } \\
\text { umum (KUHAP) }\end{array}$ & $\begin{array}{l}\text { Korban memperoleh hasil } \\
\text { dari tindakan visum et } \\
\text { repertum yang dapat } \\
\text { digunakan sebagai alat bukti } \\
\text { pelaporan. }\end{array}$ & 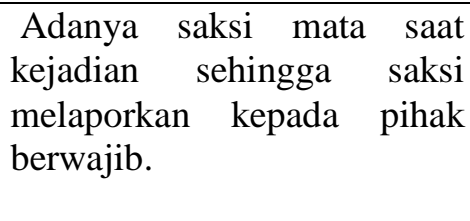 \\
\hline 2. & $\begin{array}{l}\text { Hak korban berkaitan } \\
\text { dengan kedudukannya } \\
\text { sebagai saksi dengan } \\
\text { memberikan } \\
\text { keterangan tanpa } \\
\text { tekanan }\end{array}$ & 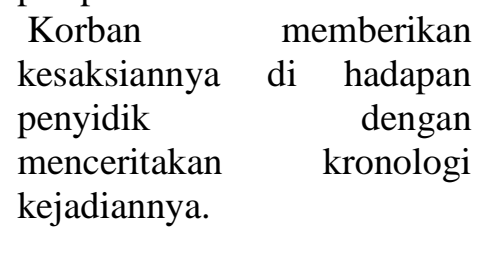 & $\begin{array}{lr}\text { Korban } & \text { memberikan } \\
\text { kesaksiannya } & \text { dengan } \\
\text { menceritakan } & \text { kronologinya } \\
\text { di hadapan penyidik. }\end{array}$ \\
\hline 3. & $\begin{array}{l}\text { Hak untuk } \\
\text { mendapatkan } \\
\text { informasi mengenai } \\
\text { putusan pengadilan. }\end{array}$ & $\begin{array}{l}\text { Korban mendapatkan } \\
\text { informasi mengenai } \\
\text { berjalannya proses peradilan } \\
\text { dan hasil putusan pengadilan } \\
\text { yang dijatuhkan kepada } \\
\text { pelaku. }\end{array}$ & $\begin{array}{l}\text { Korban beserta keluarga } \\
\text { mendapatkan informasi } \\
\text { mengenai proses berjalannya } \\
\text { peradilan dan hasil putusan } \\
\text { pengadilan terhadap pelaku. }\end{array}$ \\
\hline 4. & $\begin{array}{lr}\text { Hak bagi keluarga } \\
\text { untuk mengizinkan } \\
\text { atau } & \text { tidak } \\
\text { mengizinkan polisi } \\
\text { melakukan otopsi. }\end{array}$ & $\begin{array}{l}\text { Korban tidak menggunakan } \\
\text { haknya untuk menerima } \\
\text { ataupun menolak proses } \\
\text { otopsi dikarenakan proses } \\
\text { penyelidikan } \\
\text { membutuhkan } \\
\text { pendukung yang hanya bisa } \\
\text { diperoleh dari proses otopsi. }\end{array}$ & $\begin{array}{l}\text { Korban tidak menggunakan } \\
\text { haknya untuk menerima } \\
\text { ataupun menolak proses } \\
\text { otopsi dikarenakan proses } \\
\text { penyelidikan } \\
\text { membutuhkan } \\
\text { pendukung yang hanya bisa } \\
\text { diperoleh dari proses otopsi. }\end{array}$ \\
\hline
\end{tabular}




\subsection{Ketentuan Hukum Mengatur Perlindungan Hukum Terhadap Anak}

Korban merupakan pihak yang mengalami penderitaan bagi kerugian materiil, kerugian immaterial bahkan berakibat korban menderita luka pada tubuhnya maupun psikisnya. Penderitaan tersebut juga akan dialami oleh keluarga korban. Untuk meniadakan atau mengurangi penderitaan korban beserta keluarganya harus mendapatkan perlindungan hukum baik keamanan, bantuan hukum, pemberian informasi, pelayanan/bantuan medis maupun pemberian restitusi dan kompensasi. Perlindungan hukum korban dalam bentuk keamanan, korban, pelapor, dan saksi beserta keluarga selalu mendapatkan bujukan, ancaman, teror, dan tindakan kekerasan dari pihak pelaku tindak pidana tersebut diatas dengan tujuan agar korban, pelapor, dan saksi memberi keterangan yang dapat membebaskan atau meringankan pelaku tindak pidana atau mencabut keterangan yang telah diberikan baik kepada penyidik, penuntut umum maupun dalam pemeriksaan sidang pengadilan atau tidak datang atau tidak bersedia menjadi saksi atau memberi keterangan apapun mengenai keterlibatan pelaku tindak pidana dihadapan aparat penegak hukum. Perlindungan hukum korban dalam bentuk bantuan hukum, sangat penting untuk menimbulkan keberanian dan tidak takut dalam memberikan keterangan, informasi dan menunjukkan bukti-bukti terjadinya tindak pidana serta menyebutkan siapa pelaku tindak pidana baik dihadapan penyidik, penuntut umum dan pemeriksaan dalam sidang pengadilan. Perlindungan hukum korban dalam bentuk pelayanan/bantuan medis, sangat penting bagi korban, pelapor dan saksi yang mengalami penderitaan fisik, antara lain penganiayaan, penyiksaan, perkosaan selain untuk kepentingan visum et repertum, juga perawatan dan pelayanan medis sampai sembuh dengan biaya ditanggung oleh pelaku tindak pidana dan pemerintah. Perlindungan hukum korban dalam bentuk pemberian restitusi dan kompensasi, dengan tujuan memberikan jaminan keadilan bagi korban yang telah mengalami penderitaan baik fisik, mental, materiil maupun immaterial akibat terjadinya tindak pidana. Restitusi dapat berupa:

a. Pengembalian hak milik

b. Pembayaran ganti kerugian untuk kehilangan atau penderitaan

c. Penggantian biaya penguburan dan uang duka cita

Kompensasi merupakan bentuk santunan yang dapat dilihat dari aspek kemanusiaan dan hak-hak asasi. Kompensasi timbul dari permintaan korban dan dibayar oleh masyarakat atau merupakan bentuk pertanggungjawaban masyarakat atau negara, sedangkan restitusi lebih bersifat pidana, yang timbul dari putusan pengadilan pidana dan dibayar oleh terpidana atau merupakan wujud pertanggungjawaban terpidana (the responsibility of the offender). Stephen Schafer, menyebutkan terdapat empat sistem pemberian restitusi dan kompensasi kepada korban tindak pidana, sebagai berikut:

a. Ganti rugi (damage) yang bersifat keperdataan, diberikan melalui proses perdata. Sistem ini memisahkan tuntutan ganti rugi korban dari proses pidana. 
b. Kompensasi yang bersifat keperdataan diberikan melalui proses pidana.

c. Retitusi yang bersifat perdata dan bercampur dengan sifat pidana diberikan melalui proses pidana. Walaupun restitusi disini tetap bersifat keperdataan, tidak diragukan sifta pidananya. Salah satu bentuk restitusi menurut system ini adalah denda kompensasi. Denda ini merupakan kewajiban yang bernilai uang yang dikenakan kepada terpidana sebagai suatu bentuk pemberian ganti rugi yang seharusnya diberikan.

d. Kompensasi yang bersifat perdata, diberikan melalui proses pidana dan didukung oleh sumber-sumber penghasilan negara. Disini kompensasi tidak mempunyai aspek pidana apapun, walalupun diberikan dalam proses pidana. Jadi kompensasi tetap merupakan lembaga keperdataan murni, tetapi negaralah yang memenuhi atau menanggung kewajiban ganti rugi yang dibebankan pengadilan kepada pelaku. Hal ini merupakan pengakuan bahwa negara telah gagal menjalankan tugasnya melindungi korban dan gagal mencegah terjadinya tindak pidana.

Ketentuan yang mengatur perlindungan terhadap anak terdapat dalam Pasal 80 Undang-Undang Nomor 35 tahun 2014 ditentukan sanksi bagi pelaku kejahatan terhadap anak, yaitu:

a. Setiap orang yang melanggar ketentuan sebagaimana dimaksud dalam Pasal 76C, dipidana dengan pidana penjara paling lama tiga tahun enam bulan dan/atau denda paling banyak tujuh puluh dua juta rupiah.

b. Dalam hal anak sebagaimana dimaksud pada ayat (1) luka berat, maka pelaku dipidana dengan pidana penjara paling lama lima tahun dan/atau denda paling banyak seratus juta rupiah.

c. Dalam hal anak sebagaimana dimaksud pada ayat (2) mati, maka pelaku dipidana dengan pidaa penjara paling lama lima belas tahun dan/atau denda paling banyak tiga miliar rupiah.

d. Pidana ditambah sepertiga dari ketentuan sebagaimana dimaksud pada ayat (1), ayat (2), dan ayat (3) apabila yang melakukan penganiayaan tersebut orang tuanya.

Undang-Undang Republik Indonesia Nomor 31 Tahun 2014 tentang Perubahan Atas Undang-Undang Nomor 13 Tahun 2006 tentang Perlindungan Saksi dan Korban memberikan perlindungan dan bantuan terhadap saksi maupun korban. Perlindungan dimaksud adalah dalam bentuk perbuatan yang memberikan tempat bernaung atau perlindungan bagi seseorang yang membutuhkan sehingga merasa aman terhadap ancaman sekitarnya.

\section{Simpulan}

1. Hak-Hak Anak yang menjadi korban tindak penganiayaan ditinjau dari kedua kasus yang penulis jadikan sebagai objek penelitian adalah sebagai berikut: 
a. Hak untuk melakukan kontrol terhadap penyidik dan penuntut umum (KUHAP) dalam kedua kasus tersebut terpenuhi haknya dengan adanya fakta yang tercantum pada hasil putusan pengadilan yang disahkan oleh hakim.

b. Hak korban berkaitan dengan kedudukannya sebagai saksi dengan memberikan keterangan tanpa tekanan dalam kedua kasus tersebut terpenuhi. Korban dalam kedua kasus tersebut telah memberikan kesaksisannya di hadapan penyidik yang dijadikan sebagai acuan hakim dalam pengambilan keputusan atas Putusan tersebut.

c. Hak untuk mendapatkan informasi mengenai putusan pengadilan. Dalam kedua Putusan yang penulis gunakan dalam penelitian ini membuktikan bahwa hak korban anak untuk mendapatkan informasi mengenai putusan pengadilan telah terpenuhi dengan dicantumkannya putusan hakim dalam Putusan tersebut.

d. Hak bagi keluarga untuk mengizinkan atau tidak mengizinkan polisi melakukan otopsi. Pada kasus yang penulis gunakan sebagai objek penelitian ini, para korban tidak membutuhkan proses otopsi dikarenakan tidak mengalami kematian. Sehingga dapat disimpulkan bahwa haknya tidak tidak terpenuhi.

2. Ketentuan Hukum Mengatur perlindungan hukum terhadap anak

Hasil putusan yang diberikan oleh hakim dalam menjatuhkan hukuman pidana bagi pelaku tindak pidana dilihat berdasarkan perbuatan pelaku yang merugikan korban dan akibat dari perbuatan pelaku tindak pidana. Dalam menentukan hukuman untuk pelaku, hakim juga mempertimbangkan dari faktor-faktor yang meringankan dan membertakan pelaku tindak pidana.

\section{Daftar Pustaka}

\section{Peraturan Perundang-undangan:}

Kitab Undang-Undang Hukum Pidana.

Undang-Undang Nomor 4 Tahun 1979 tentang Kesejahteraan Anak;

Undang-Undang Nomor 11 tahun 2012 tentang Sistem Peradilan Pidana Anak

Undang-Undang Nomor 35 tahun 2014 tentang Perubahan Atas Undang-Undang Nomor 23 Tahun 2002 tentang Perlindungan Anak;

Undang-Undang Republik Indonesia Nomor 31 Tahun 2014 Tentang Perubahan Atas Undang-Undang Nomor 13 Tahun 2006 tentang perlindungan Saksi dan Korban

\section{Buku:}

Abdussalam. 2010. Victimology. Jakarta: PTIK Press 
Maidin Gultom. 2014. Perlindungan Hukum Terhadap Anak Dalam Sistem Peradilan Pidana Anak di Indonesia. Bandung: Refika Aditama

Moerti Hadiati Soeroso. 2010. Kekerasan Dalam Rumah Tangga Dalam Perspektif Yuridis Viktimologis. Jakarta: Sinar Grafika

\section{Jurnal Online:}

https://dspace.uii.ac.id/bitstream/handle/123456789/1607/05.2\%20bab\%202.pdf?sequen $\underline{\mathrm{ce}=8 \& \text { isAllowed }=y}$, dilihat pada hari Senin, 21 September 2020, jam 18.23 WIB

http://repository.unpas.ac.id/12206/5/BAB\%20II.pdf , dilihat pada hari Selasa, 22 September 2020, jam 15.20 WIB

\section{Website:}

Hasmiah Hamid. (2018). Perlindungan Hukum Terhadap Korban Penganiayaan Dalam Penanganan Tindak Pidana Di Indonesia. Diakses pada hari Jumat, 9 Oktober 2020, jam 15.26 WIB https://osf.io/q4hbr/download/

Tirsha Aprillia Sinewe. (2016). Perlindungan Hukum terhadap Anak sebagai Korban Kejahatan Menurut Hukum Pidana Indonesia. Diakses pada hari Selasa, 22 September 2020, jam $\quad 17.33 \quad$ WIB https://www.neliti.com/publications/145898/perlindungan-hukum-terhadap-anaksebagai-korban-kejahatan-menurut-hukum-pidana-i 